\title{
STRATEGI PENGEMBANGAN ECOTOURISM PULAU DERAWAN KABUPATEN BERAU KALTIM
}

\author{
Oleh \\ Policharpus Raja Peta
}

Alumni Jurusan Pariwisata Politeknik Negeri Samarinda, Alamat, Kota Samarinda 75131, Indonesia Jl. DR. Ciptomangunkusumo, Kampus Gunung Lipan, Samarinda, Kalimantan Timur, Indonesia 75131 | Hot line: PABX (+62541) 260588, FAX: (+62541) 260355

ARTICLE INFO

Article history:

Received 2 Feb 2019

Revised 1 April 2019

Accepted 5 Juni 2019

\section{Mengajukan ISSN}

Keywords: Ecotourism Management

\section{ABSTRACT}

The ecotourism potensial is very interested becouse the island montioned to have tourism potential is tourism culture and tourism nature. Get data with used of description technique research and qualitative technique research. From research proceeds about the ecotourism management to experience negative impact of tourism inviromental. Like a rubbish and too more facilities, becouse the level international tourist visited from 2010 years till to 2011 years down proceeds. But the domestic tourist still stable.

Copyright (C) 2019 Politeknik Negeri Samarinda.

All rights reserved.

\section{Pendahuluan}

Kegiatan wisata alam yang dilakukan serta dikembangkan pada suatu kawasan yang mana pada prinsipnya digolongkan menjadi, wisata darat meliputi lintas alam, mendaki gunung, menelusuri gua, berburu, fotografi, rekreasi pantai, berkemah, penelitian dan pendidikan serta wisata bahari yaitu berenang, menyelam dan snorkling, berlayar, berselancar, fotografi, memancing, rekreasi pantai, penelitian, pendidikan. (Mellawati et al., 2010). Pengembangan pariwisata, termasuk di dalamnya wisata alam dapat memberikan manfaat dan keuntungan, yaitu : meningkatkan kesadaran masyarakat untuk berperan secara aktif dalam pelestarian lingkungan, pertukaran latar belakang budaya yang berbeda, membuka kesempatan kerja dan berusaha, dan meningkatakan pendapatan negara. (Budy Wiryawan et al., 2004).

Kalimantan Timur merupakan salah satu provinsi yang kaya akan potensi alam dengan panorama yang indah dan keunikan serta kekhasannya. Apabila potensi ini mampu dikembangkan secara optimal maka Kalimantan Timur dapat menjadi satu diantara daerah tujuan wisata yang menarik banyak wisatawan.

Dari beberapa kawasan konservasi yang ada di Kalimantan Timur, pengembangan lebih lanjut untuk dapat memberikan kontribusi pemasukan bagi daerah belum banyak dikembangkan. Saat ini, kawasan konservasi tersebut hanyalah dijadikan sebagai areal penelitian. Namun demikian daerah tujuan wisata tersebut belum mampu menarik wisatawan dalam jumlah besar dan menjadi kawasan konservasi yang ideal, hal ini 
disebabkan oleh banyak faktor. Beberapa faktor utama yang menjadi kendala adalah rendahnya aksesibilitas, manajemen yang kurang profesional dan keamanan kawasan dari tekanan penduduk disekitar kawasan dan faktor alam.

Berau merupakan salah satu kabupaten yang terletak di Provinsi Kalimantan Timur, yang memiliki potensi wisata Pulau Derawan. Berau mempunyai sumber daya alam laut dan daratan yang sangat kaya. Wilayah perairan Kabupaten Berau Kalimantan Timur, terletak di laut Sulawesi adalah salah satu pusat keanekaragaman hayati dunia.

Adapun potensi atau produk ekowisata yang dimiliki di kepulauan Derawan ialah : 1) Penyu hijau, 2) Terumbu karang, 3) Ikan manta, 4) Empat spesies ubur-ubur yaitu : a) Aurelia Aurita (Transparan), b) Tripedalia Cystophora (Ukuran Kecil), c) Mastigias Papua (Paling Banyak), d) Cassiopeia Ornata (Selalu Terbalik), 4) Pelbagai macam spesies ikan laut, 5) Fasilitas yang cukup memadai, 6) Budaya masyarakat setempat.

Meskipun demikian belum maksimal dimanfaatkan untuk pengelolaan ekowisata, karena kurangnya kesadaran masyarakat pulau derawan terhadap perlindungan satwa, ada beberapa satwa lindung yang menjadi sumber penghasilan masyarakat lokal yakni: karapas penyu sisik, penyu sisik yang di permalin, pengrusakan terumbu karang, penangkapan ikan dengan menggunakan potasium, dan pukat harimau, hasil pencaharian tersebut kemudian dijual kepada wisatawan. Semua permasalahan yang terkait dengan penyalahgunaan sumberdaya alam ternyata untuk kebutuhan ekonomi masyarakat, Menurut penulis hal-hal inilah yang menjadi penyebab hampir punahnya satwa-satwa tersebut.
Dengan demikian pengelolaan ekowisata seharusnya bukan saja memberikan dampak ekonomi bagi masyarakat tetapi juga memberikan perlindungan alam, dengan pengelolaan ekowisata yang baik dapat memberikan manfaat yang berkelanjutan.

\section{Metode Penelitian}

Penelitian ini adalah jenis penelitian survey dengan menggunakan pendekatan deskriptif kualitatif yaitu proses penelitian dan pemahaman yang berdasarkan pada metodologi yang menyelidiki dan mendeskripsikan fenomena-fenomena yang ada pada obyek penelitian.

\section{a. Metode Pengumpulan Data}

Untuk mendapatkan data-data yang dibutuhkan dalam penelitian ini, digunakan metode pengumpulan data sebagai berikut:

1) Observasi adalah pengamatan langsung terhadap fenomenafenomena yang berhubungan dengan Pengembangan ekowisata yang ada pada Pulau Derawan.

2) Wawancara merupakan Proses memperoleh keterangan, informasi, dengan cara menanyakan pada pengelola, tokoh masyarakat dengan menggunakan pedoman wawancara.

3) Kuesioner adalah daftar pertanyaan yang diberikan kepada responden untuk menjawab pertanyaan yang terkait dengan Pengembangan ekowisata di Pulau Derawan.

4) Studi pustaka merupakan cara pengumpulan data yang dari buku referensi, penelitian ilmiah, internet dan dokumendokumen lainnya yang relevan 
dengan pengembangan ekowisata di Pulau Derawan.

\section{Pembahasan}

Berdasarkan hasil penelitian penulis, Pulau Derawan memiliki potensi wisata yang sangat baik sebagai ekowisata karena memiliki daya tarik seperti penyu laut dan terumbu karang sehingga Pulau Derawan masuk pada urutan ke-14 daerah tujuan (destinasi) Nasional, namun demikian dari pihak-pihak yang terkait dalam pengembangan ekowisata di Pulau Derawan kurang maksimal dikelola dengan baik diantaranya yaitu, kondisi Atraksi Wisata, Kondisi Aksesibilitas, dan Kondisi Fasilitas (Amenitas), yang tersedia di obyek wisata Pulau Derawan, masih kurang dikembangkan dan dikelola dengan baik. Dengan pengembangan yang kurang maksimal dapat berpengaruh negatif bagi kesejahteraan masyarakat lokal.

\section{a. Pengelolaan Atraksi Wisata}

Pengelolaan atraksi wisata sangatlah penting, karena atraksi wisata merupakan salah satu yang paling utama yang berpengaruh pada minat kunjungan wisatawan.

1. Kondisi atraksi wisata alam yang ada di Pulau Derawan adalah sebagai berikut :

a. Penyu Hijau (chelonia mydas)

Penyu laut merupakan satwa langka yang yang sangat unik karena penyu hijau datang kepinggir pantai dan bertelur pada malam hari uniknya lagi jumlah telur penyu ini mencapai ratusan sehingga menjadi icon Kabupaten Berau. Namun demikian keberadaan penyu hijau ini hampir punah karena dari masyarakat lokal saat ini masih mengeksploitasi telur penyu akibat kurangnya pemahaman masyarakat lokal terhadap efek samping telur penyu yaitu apabila telur penyu dikonsumsi terlalu banyak maka akan menjadi racun hal ini dikarenakan banyaknya kandungan protein yang tinggi dan kandungan zat lemak tak jenuh. Berdasarkan informasi harga 1 (satu) butir telur penyu sebesar Rp. 6.000,- sehingga masyarakat lokal tergiur untuk mengeksploitasi telur tersebut.

Selain dari pada itu, kurangnya kesadaran driver bout dalam mengendarai speedbout di daerah pinggiran pantai sehingga dapat melukai penyu saat berenang mencari makan dikarenakan baling-baling speedbout. Hal-hal inilah yang menyebabkan terganggunya populasi penyu hijau di Pulau Derawan, sebaiknya hal seperti ini perlunya peran pihak pemerintah dalam menegaskan undang-undang No.07 Tahun 1999 mengenai kawasan konservasi satwa lindung. Sehingga keberadaannya dapat terlindungan.

b. Padang Lamun (Sea Grass)

Berdasarkan penelitian Padang lamun ini merupakan "ruaya pangan" penyu laut. Kondisi padang lamun di Pulau Derawan mulai berkurang populasinya dikarenakan beberapa faktor yaitu, kurangnya terumbu karang di sekitar Pulau Derawan sehingga ketika ombak datang terjadi abrasi pantai sehingga pasir menutupi padang lamun. Selain itu karena aktivitas masyarakat lokal dengan membuang jangkar kapal pada areal padang lamun sehingga padang lamun atau sea grass banyak yang rusak, hal ini dapat menyebabkan dampak negatif terhadap penyu laut karena kehilangan "ruaya pengan". Pihak 
pengelola mencari solusi seperti membuat larangan keras tentang, jangan mengendarai speedbout atau kapal cepat sehingga keberadaan padang lamun disekitar Pulau Derawan dapat terlindungi oleh karang. Disamping itu juga perlunya sosialisasi terhadap masyarakat lokal tentang penerapan sadar wisata dengan membina POKDARWIS (kelompok sadar wisata) yang ada. Dengan demikian penyu laut tidak kehilangan "ruaya pangan" atau sistem jaringan makanan tidak putus.

c. Terumbu Karang (coral reef)

Terumbu karang merupakan benteng pertahanan dalam perlindungan pulau dari ombak laut, sehingga selain daya tariknya yang indah, terumbu karang juga sebagai penyanggah ombak dari abrasi.

Berdasarkan penelitian kondisi terumbu karang di sekitar Pulau Derawan sudah banyak yang rusak hal tersebut dikarenakan sebagian dari masyarakat lokal yang memilih cara praktis untuk memperoleh ikan dengan menggunakan bahan peledak dan aktivitas transportasi speedboat dengan kecepatan tinggi, sehingga banyak terumbu karang yang rusak dan mengakibatkan segala jenis ikan akan punah. Sebagai pihak yang terkait dalam pengelolaan Pulau Derawan, pemerintah memberikan penegasan sesuai dengan Surat Keputusan (SK) Bupati Berau No.660/151/BPLDSET/2003 mengenai monitoring pengawasan pengamanan konservasi sumber daya alam (SDA).

d. Panorama Alam

Pulau Derawan memiliki panorama yang indah karena masih bisa menyaksikan matahari terbit (sunset), matahari terbenam (sunrise), dan pemandangan bawah laut.

Namun demikian kondisi panorama alam saat ini mulai terganggu dengan akomodasi yang melebihi daya tampung, disamping itu juga pembangunannya terlalu memanjang ke laut dan limbah sampah non-organik dan organik yang berserakan disekitar akomodasi dan pantai.

Hal ini hanya dapat dihentikan dengan membuat peraturan tentang larangan dan pemberhentian tentang pembangunan akomodasi karena sudah melebihi kapasitas dan TPA (tempat pembuangan akhir) limbah sampah sebaiknya dibuang ke Pulau Rabu-Rabu yang tidak berpenghuni.

e. Ikan karang

Pulau Derawan terdapat berbagai macam jenis ikan yang memiliki suku, salah satunya adalah jenis ikan kerapu, adalah suku Serranidae. Jenis ikan ini terdapat di areal karang dan ikan kerapu ini dapat membantu perkonomian masyarakat lokal yang bekerja sebagai nelayan karena harganya yang relatif mahal yaitu berkisar antara Rp. 100.000,- per 3 (tiga) On. Selain itu jenis-jenis ikan karang ini menambah keunikan daya tarik wisata saat wisatawan melakukan diving.

Namun keberadaan ikan karang ini mulai menurun populasinya karena aktivitas dari masyarakat lokal yang ingin menggunakan cara cepat memperoleh ikan dengan bahan peledak, hal ini dapat merugikan banyak faktor seperti hancurnya karang, semua jenis ikan bisa 
punah mulai dari ikan yang besar hingga ikan yang kecil. Hal-hal demikian dari pihak pemerintah harus mempertegas lagi undangundang mengenai konservasi laut.

f. Perikanan

Kondisi perikanan saat ini cukup stabil karena masyarakat Kecamatan Kepulauan Derawan di fasilitasi dan dibimbing oleh Lembaga Swadaya Masyarakat (LSM) nasional yaitu LSM WWF (world wide found) dalam devisi Fisheris (perikanan).

2. Kondisi Atraksi Wisata Budaya

Tarian Daling dan Tarian Igal

Tarian Daling ini digunakan pada saat acara pernikahan dan Tarian Igal digunakan pada saat acara pesta laut. Seharusnya digunakan untuk menyambut tamu atau menampilkan kedua seni tari tersebut pada hari tertentu misalkan pada hari minggu dikhususkan untuk wisata budaya seni tari sehingga pengunjung atau wisatawan dapat merasakan budaya masyarakat lokal di Pulau Derawan.

3. Kondisi atraksi Wisata Buatan

Berdasarkan penelitian kondisi wisata buatan di Pulau Derawan berupa taman rekreasi. Namun wisata buatan ini baru dalam proses pembuatan.

Menurut penulis sangat setuju dengan adanya jenis wisata ini karena akan menambah atraksi wisata di Pulau Derawan, akan tetapi penempatan lokasi pembuatan taman rekreasi ini tidak efektif karena berada di areal konservasi penyu hijau, apabila tindakan permerintah seperti ini maka populasi penyu hijau akan terganggu. Disamping itu dapat mengganggu panorama sekitar obyek wisata. Dari pihak yang terkait dengan pengelolaan Pulau Derawan sebaiknya memindahkan taman rekreasi ini di dekat lapangan bola Pulau Derawan karena lahan disekitar lapangan tersebut masih luas.

\section{b.Aksesibilitas}

Aksesibilitas merupakan salah satu sarana penting dalam pencapaian obyek wisata, maka dari itu perlunya transportasi yang memadai serta infrastruktur jalan yang baik sehingga mempermudah pengunjung atau wisatawan untuk berwisata. Demikian pula dengan aksesibilitas ke Pulau Derawan masih belum memadai.

Berikut adalah kondisi aksesibilitas menuju pulau Derawan :

- Tidak adanya harga standar untuk transportasi sehingga adanya perbedaan harga antara pengunjung lokal dan non lokal karena keingan masyarakat dalam mencari keuntungan sebesar-besarnya.

- Infrastruktur jalan banyak yang rusak

- Tidak adanya angkutan umum dari Bandara Kalimarau menuju Dermaga Tanjung Batu.

Berdasarkan hasil pengamatan bahwa hal-hal tersebut dapat membingungkan pengunjung, sehingga perlu adanya inovasi yang baru sehingga wisatawan atau pengunjung dapat merasakan kenyamanan dan kemudahan dalam perjalanannya menuju pulau Derawan seperti sediakan shuttle bus (angkutan umum), kapal penumpang untuk menyeberang ke Pulau Derawan, perbaiki infrastuktur jalan yang rusak, dan penetapan harga speed boat.

\section{c. Fasilitas (Amenitas)}

Pada dasarnya keberadaan amenitas yang memadai di suatu obyek wisata merupakan salah satu unsur penting, amenitas di Pulau Derawan sudah sudah memadai. Hal tersebut berguna dalam menunjang aktivitas wisatawan di obyek wisata. Oleh karena itu kondisi amenitas pada obyek wisata harus dapat diperhatikan dengan baik agar wisatwan dapat merasa betah dan nyaman berada 
disuatu obyek wisata. Demikian pula dengan obyek wisata Pulau Derawan. Kondisi pembangunan sangat memadai, namun kurang memberikan kenyamanan terhadap wisatawan karena padatnya pembangunan yang mengarah ke laut baik losmen maupun resort yang mengakibatkan panorama alam dan terumbu karang terganggu.

Berikut adalah kondisi fasilitas obyek wisata yang tersedia hingga saat ini di Pulau derawan :

1. Losmen

Berdasarkan hasil penelitian, kondisi losmen yang tersedia di Pulau Derawan sudah melebihi batas makimum pembangunan losmen, karena bangunan losmen sudah banyak dan terlalu jauh memanjang ke laut sehingga berakibat buruk pada panorama, daya tarik obyek wisata, lingkungan dan kelebihan daya tampung wisatawan. Seharusnya pihak pengelola mebuat peraturan untuk pemberhentian pembangunan losmen, karena banyaknya jumlah losmen jika keberadaannya tidak diperhitungkan dan jumlah wisatawan yang berkunjungpun sedikit akan menimbulkan kecemburuan dan persaingan antara kompetitor losmen.

2. Resort

Berdasarkan hasil pengamatan penulis kondisi resort di pulau Derawan ada 2 resort yaitu PT. Bumi Manimbora Interbuana Resort, Derawan Dive Lodge Resort. Meskipun demikian dari resort yang ada cuma satu resort yang mempunyai izin lengkap yaitu PT. Bumi Manimbora Interbuana (BMI). PT. BMI di resmi di buka pada tahun 1993 dan memperoleh izin dari Kementrian Pariwisata pada tahun 1999 dengan jangka waktu 7 (tujuh) tahun lamanya untuk memperoleh izin tersebut sedangkan Derawan Dive Lodge Resort di resmi di buka pada tangga 01 januari 2012 dan baru memperoleh izin dari kepala kampung karena untuk membuat surat izin usaha prosesnya cukup lama dan rumit yaitu dengan jangka waktu 7 (tujuh tahun) untuk memperoleh surat izin usaha. Disamping itu terdapat dampak negatif pula dengan resort karena kedua resort ini sama halnya dengan losmen yaitu pembangunannya memanjang ke laut.

Dari pihak yang terkait memberikan penegasan dalam pengarahan melalui sosialisasi tentang pembangunan yang ramah lingkungan obyek wisata dan memberi peraturan untuk berhenti membangun sampai memanjang ke laut sehingga tidak merusak panorama laut.

\section{Home stay}

Berdasarkan hasil penelitian home stay yang ada di pulau Derawan sangat banyak dari RT. 1 hingga RT. 4 namun yang ada papan namanya cuma 4 home stay yaitu home stay dina, home stay dona, home stay walmas, dan home stay arlisa. Home stay yang tidak diberi papan nama yaitu rumah yang berwarna cat hijau, digunakan apabila ada pagelaran acara seperti acara Pekan Olah Raga Nasional (PON) tahun 2008 lalu.

4. Pendopo atau gedung serba guna

Berdasarkan hasil penelitian kondisi pendopo ini digunakan untuk segala bentuk acara. Meskipun demikian penempatan pendopo tidak tepat karena posisi pendopo berada di areal konservasi penyu hijau sehingga dapat berpengaruh negatif terhadap penyu karena penyu rentang terhadap cahaya dan tempat untuk bertelurpun berkurang akibat pendopo tersebut. Memang betul untuk pengadaan pendopo tetapi seharusnya jangan di tempat konservasi karena akan mempersulit proses bertelurnya penyu laut.

5. Taman wisata buatan

Berdasarkan pengamatan taman wisata buatan di pulau Derawan 
kurang tepat karena pulau derawan merupakan obyek ekowisata. Selain itu taman wisata yang baru di buat letaknya dekat dengan kawasan konservasi penyu hijau hal ini yang berakibat buruk juga pada satwa. Seharusnya jangan di buat taman wisata buatan apabila tetap di buat pulau derawan ini akan semakin padat dengan pembangunan yang merusak panorama dan daya tarik wisata.

6. Dive centre danakan

Berdasarkan hasil pengamatan kondisi dive centre danakan bertempat di losmen danakan yang di handle atau dipandu oleh license free dive guide master. Harga standar dive $\mathrm{Rp}$. 300.000,- dan kalau belum memiliki sertifikat biayanya sebesar Rp. 500.000,-

7. PT. Mitra Abadi Tour and travel

Berdasarkan hasil penelitian kondisi PT. Mitra Abadi tour and travel mengemas paket wisata untuk kepulauan Derawan dan tiket pesawat untuk penerbangan domestik.

\section{Banana Bout}

Banana bout di Pulau Derawan kondisinya masih bagus dan biaya sewanya pun relatif murah yaitu sebesar Rp. 200.000,- untuk satu putaran mengelilingi Pulau Derawan. Namun demikian banana bout dapat berpengaruh buruk pada populasi penyu laut dikarenakan speedbout melintas dekat pantai sehingga populasi penyu dapat terganggu.

Hasil diatas menunjukkan bahwa kurangnya kepedulian dari pihak yang terkait, maka perlunya sosialisasi terhadap masyarakat lokal tentang penerapan sadar wisata.

9. Cinderamata (Souvenir)

Berdasarkan hasil penelitian pihak pemerintah sudah memberikan pelatihan terhadap masyarakat pulau Derawan untuk pembuatan cinderamata dari kerang dan memberikan fasilitas berupa alat untuk pembuatan cinderamata. Meskipun demikian kondisi cendera mata khas Derawan masih banyak terbuat dari sisik penyu laut karena mayoritas pengunjung lokal mengkonsumsi cinderamata tersebut. Disamping itu bahan-bahan pakaian dan pembuatannya dipesan dari Bali. Seharusnya dari pihak yang terkait dengan pengelolaan pulau Derawan memberikan penegasan dan solusi melalui sosialisasi untuk larangan menggunakan bahan-bahan dari sisik penyu.

10. Masker and Fin

Masker dan fin ini digunakan untuk snorkling dan kondisi barangnya pun bagus, biaya sewa fin dan masker dalam sehari sebesar Rp.50.000,-

\section{d. Pihak-Pihak Yang Terkait Dalam Pengembangan Ekowisata}

Pihak-pihak yang terkait dalam pemberdayaan masyarakat dalam pengembangan ekowisata di Pulau Derawan sebagai pembuat kebijakan dalam menetapkan peraturan undang undang daerah, strategi, peningkatan fasilitas, promosi dan penyuluhan atau sosialisasi, disamping itu pihak LSM (Lembaga Swadaya Masyarakat) yaitu WWF (World Wide Found) sebagai pihak konservasi yang bersifat non profit, selain itu pihak industri pariwisata sebagai pengusaha atau pihak swasta dibidang pariwisata seperti pengusaha resort dan masyarakat sebagai pengelola utama yang memberikan izin tentang pengembangan ekowisata di Pulau Derawan.

Berdasarkan pihak-pihak yang terlibat dalam pengembangan ekowisata diatas, para pihak tersebut memiliki peran dan tanggung jawab yaitu pemerintah menetapkan peraturan daerah salah satunya yaitu dengan menetapkan dan mengeluarkan Surat Keputusan (SK) Bupati Berau No.660/151/BPLDSET/2003 mengenai monitoring pengawasan pengamanan konservasi sumber daya alam (KSDA), kemudian 
strategi pemerintah dalam mengembangkan ekowisata di Pulau Derawan yaitu, 1). Melakukan promosi yang gencar mulai dari media elektronik (website, internet, televisi, radio), media cetak (brosur, koran, majalah) pameran dan mengikuti event- event nasional. 2). Mengembangkan lapangan pesawat terbang guna mempermudah akses menuju Tanjung Redeb dan ke pulau Derawan. 3). Memberikan pelatihan untuk masyarakat dan juga membentuk kelompok sadarwisata atau disingkat “ PODARWIS “ yang bertujuan untuk meningkaktkan pemasukan masyarakat setempat. 4). Melakukan kerjasama terhadap stakeholder dalam hal pelestarian lingkungan untuk menjaga lingkungan agar tetap lestari. 5). Mencari sosulisi terkait sampah TPA ( Tempat Pembuangan Akhir ) di pulau Derawan. 6). Membangun fasilitas pendukung pariwisata di pulau Derwan dan sekitarnya berupa panggung pariwisata, dermaga, wc umum, kotak sampah.

Kemudian peran pemerintah dalam meningkatkan fasilitas penunjang yaitu pembangunan prasarana berupa pendopo dan taman rekreasi yang masih dalam proses pembuatan. Namun pemanfaatan dana dalam pembangunan prasarana tersebut tidak sesuai dengan konsep ekowisata yaitu tanpa merubah kondisi alam sekitar. Pemanfaatan tata ruangnya tidak tepat guna karena lokasi pembangunannya berada pada kawasan konservasi satwa penyu laut yang mengakibatkan terganggunnya populasi penyu.

$\begin{array}{ccc}\text { Peran } & \text { pemerintah } & \text { dalam } \\ \text { mempromosikan } & \text { pariwisata } & \text { Pulau }\end{array}$ Derawan dinilai sudah baik dan efektif, hal ini dibuktikan dengan kegiatan promosi melalui periklanan dengan menggunakan website, internet, televisi, radio, media cetak, brosur, koran, majalah. Dan mengikuti kegiatan pameran serta mengikuti event- event nasional.

$$
\text { Peran pemerintah dalam }
$$
mensosialisasi sudah maksimal yaitu melalui kelompok Sadar Wisata (POKDARWIS). Namun pemerintah kurang memberikan pendidikan dan pemahaman tentang manfaat dan keuntungan pariwisata kepada masyarakat lokal, sehingga masih ada masyarakat lokal yang merusak ekosistem laut. Dengan demikian pihak pemerintah harus lebih berperan dalam memberikan pendidikan dan pengetahuan sehingga dapat berlangsungnya kesejahteraan masyarakat lokal.

Peran dan tanggung jawab lembaga swadaya masyarakat (LSM) yaitu WWF dalam menjaga ekosistem laut dengan melakukan upaya konservasi di Pulau Derawan, namun upaya konservasi yang dilakukan kurang maksimal karena kurangnya dukungan dari masyarakat lokal akibat kurangnya pemahaman dan pengatahuan masyarakat terhadap keuntungan dan manfaat konservasi sumberdaya alam hayati yang secara langsung dapat memberikan kesejahteraan bagi masyarakat lokal sehingga masyarakat lokal kurang setuju dengan keberadaan LSM WWF di Pulau Derawan. Dalam hal ini pemerintah juga kurang memperhitungkan dampakdampak negatif dari pengembangan pariwisata di Pulau Derawan yang akan terjadi, seperti membangun panggung pariwisata di area sektor B konservasi satwa penyu dan pembuatan taman rekreasi di area sektor $\mathrm{C}$ konservasi satwa penyu, sehingga akibat tindakan yang tidak sesuai dengan strategi pemerintah diatas, pihak lembaga swadaya masyarakat khususnya WWF mengalami kesulitan dalam mengupayakan konservasi satwa penyu laut di Pulau Derawan.

Peran dan tanggung jawab pihak industri pariwisata seperti pihak swasta (pengusaha bidang pariwisata) mendukung kepariwisataan di Pulau Derawan diantaranya, membuka lapangan pekerjaan baru, penyerapan tenaga kerja, secara tidak langsung dampak multi playernya dapat meningkatkan 
kesejahteraan masyarakat dengan berkembangnya kepariwisataan.

Dalam peran masyarakat lokal sebagai pengelola utama, terlibat langsung dalam pengembangan ekowisata, masyarakat setempat sadar akan kepentingan kegiatan pariwisata dalam meningkatkan taraf hidup, namun tidak semua masyarakat terlibat dalam pengembangan ekowisata di Pulau Derawan, dikarenakan kurangnya sumber daya manusia (SDM) yang kreatif dan inovatif.

\section{e. Pemberdayaan Masyarakat}

Untuk meningkatkan kesejahteraan masyarakat setempat pemerintah berperan aktif dalam usaha melibatkan masyarakat setempat terhadap kegiatan kepariwisataan di Pulau Derawan. Dalam pemberdayaan masyarakat setempat pemerintah melakukan sosialisasi mengenai pemanfaatan limbah sampah dan cangkang kerang yang rusak menjadi souvenir serta memfasilitasi masyarakat dengan memberikan alat bantu dalam membuat souvenir. Namun pemahaman dan pengetahuan masyarakat tentang pemanfaatannya masih kurang sehingga masyarakat mengeksploitasi cangkang satwa penyu menjadi cincin dan gelang, penyu yang diawet, dan cangkang kerang yang masih hidup di manfaatkan.

\section{Kesimpulan dan Saran}

Berdasarkan hasil pembahasan yang telah diuraikan penulis pada bab hasil dan pembahasan sebelumnya mengenai pola pengelolaan ekowisata di Pulau Derawan Kabupaten Berau Kalimantan Timur sebagai salah satu obyek wisata alam atau ekowisata di Kabupaten Berau, maka penulis dapat menarik kesimpulan sebagai berikut, Kondisi pengelolaan atraksi wisata di Pulau Derawan cukup bagus karena keunikan atraksi wisata alamnya dapat memberikan kepuasan terhadap wisatawan atau pengunjung, seperti dapat melihat penyu hijau, terumbu karang, ikan karang dan panorama alam akan keunikannya.

Namun pengelolaan atraksi wisata alam yang ada belum dikelola dengan maksimal, sehingga banyak terumbu karang yang mulai rusak akibat aktivitas masyarakat lokal menggunakan bahan peledak untuk medapatkan ikan, disamping itu juga banyaknya sampah yang berserakan di pantai karena tidak adanya solusi Tempat Pembuangan Akhir (TPA) limbah sampah, sehingga dapat merusak panorama alam dan menurunnya populasi penyu hijau karena tindakan masyarakat lokal yang masih mengeksploitasi telur penyu untuk kebutuhan ekonomi masyarakat.

Disamping itu ada pula atraksi wisata budaya seperti tari daling dan igal, tarian ini sangat unik dan dapat menarik hasrat pengunjung. Akan tetapi jenis atraksi wisata ini jarang di tampilkan kecuali dalam acara pernikahan dan pesta laut di Pulau Derawan sehingga tidak semua wisatawan menikmatinya.

Selain itu terdapat wisata buatan yaitu berupa taman rekreasi namun masih dalam proses pembuatan. Taman rekreasi ini cukup bagus karena dapat menambah atraksi wisata di Pulau Derawan. Akan tetapi penempatan lokasi tamannya yang tidak efektif karena berada di areal konservasi penyu hijau, hal ini dapat mengganggu populasinya.

Aksesibilitas di Pulau derawan cukup bagus karena akses menuju Pulau Derawan dapat dicapai dengan pesawat udara, transportasi darat, dan laut. Namun ada beberapa faktor yang menyebabkan wisatawan bingung karena tidak adanya transportasi umum seperti bus dari Bandara Kalimarau menuju Dermaga Tanjung Batu sehingga dapat membuat wisatawan bingung.

Wisatawan asing dan wisatawan nusantara yang berkunjung ke Pulau Derawan menggunakan kendaraan sewa. Disamping itu infrastruktur jalan ada yang rusak akibat kendaraan batu bara melintas. 
Selain itu timbulnya perbedaan biaya transportasi antara pengunjung lokal dan non lokal hal tersebut dikarenakan jarak dari bandara menuju ke Dermaga Tanjung Batu cukup jauh dan kondisi jalannya pun rusak sehingga transportasi pengujung nusantara dan mancanegara relatif lebih mahal dari pada pengunjung lokal masyarakat Berau.

Kondisi fasilitas (amenitas) di Pulau Derawan cukup baik karena amenitas di Pulau Derawan sudah memadai dan dapat memenuhi kebutuhan wisatawan atau pengunjung untuk menginap dan melakukan kegiatan atraksi wisata. Akan tetapi terdapat sisi kurangnya dalam pengelolaan amenitas ini seperti kelebihan daya tampung fasilitas sehingga jumlah wisatawan yang sedikit tidak sesuai dengan fasilitas yang tersedia. Hal ini dapat menimbulkan kecemburuan sosial antara masyarakat lokal Pulau Derawan karena tidak semua fasilitas masyarakat digunakan jasanya oleh pengunjung atau wisatawan dan akhirnya timbulnya persaingan antara kompetitor.

Karakteristik wisatawan yang berkunjung ke Pulau Derawan mayoritas dari berasal dari masyarakat lokal Kabupaten Berau dan Tarakan karena jarak tempuh ke Pulau Derawan lebih dekat di banding dengan wisatawan nusantara dan mancanegara. Disamping ada faktor penyebab kurangnya minat kunjungan wisatawan karena kurangnya perawatan terhadap atraksi wisata alam seperti banyaknya sampah organik dan non organik yang berserakan di pinggir pantai dan banyaknya terumbu karang (coral reef) yang rusak. Berdasarkan pengamatan dari kuisioner kebanyakan pengunjung mengeluh mengenai sampah. hal tersebut dikarenakan kurangnya kesadaran masyarakat lokal.

Adapun beberapa saran yang penulis dapat berikan dalam pengelolaan ekowisata di Pulau Derawan Kabupaten Berau Provinsi Kalimantan Timur adalah sebagai berikut : a) Perlunya ketegasan dari pemerintah dalam merealisasikan UU No. 07 Tahun 1999 mengenai perlindungan kawasan konservasi satwa.

b) Pihak pengelola sebaiknya memperhatikan POKDARWIS (kelompok sadar wisata) yang sudah dibentuk sehingga masyarakat lokal dapat peduli dengan potensi pariwisata di Pulau Derawan.

c) Pihak pengelola sebaiknya menampilkan wisata budaya berupa tarian daling dan tarian igal kepada wisatawan atau pengunjung.

d) Pemerintah sebaiknya mengarahkan masyarakat lokal untuk Tempat Pembuangan Akhir (TPA) limbah sampah di Pulau Rabu-Rabu karena pulau tersebut tidak memilki potensi wisata dan tidak berpenghuni.

e) Perlunya peran pemerintah dalam memperhatikan infrastruktur jalan yang rusak dan penyediaan angkutan umum dari bandara menuju Terminal Umum kemudian menggunakan angkutan umum berupa Bus atau Shuttle Bus menuju Dermaga Tanjung Batu.

f) Sebaiknya pihak pemerintah cepat menanggulangi ketidak tetapan biaya transportasi bagi pengunjung nusantara dan mancanegara dengan menetapkan biaya transportasi dan meyediakan informasi umum di Bandara mengenai transportasi dan biayanya.

g) Perlunya membuat peraturan untuk larangan pembangunan akomodasi karena Pulau Derawan sudah kelebihan daya tampung wisatawan. 


\section{DAFTAR PUSTAKA}

Cole,Stroma, Cultural Tourism

Community Participation and

Empowerment,

In Melanie K. Smith and Mike Robinson " Cultural Toruism in a changing word polities participation and (Re) Presentation" British; Channel View Publication, 2006

Fandeli,Chafid, Perencanaan Kepariwisataan Alam, Yogyakarta, Fakultas Kehutanan UGM, 2002

Gunawan Sumodiningrat, Pembangunan Daerah dan Pemberdaya Masyarakat, Jakarta, PT.Bina Rena Parisara, 1996

Gatot Sudarto, 2000;15-16, Merencanakan dan Mengelola Pondok Ekowisata, Bekasi, Yayasan Kalpatur Bahari.

Moleong, Lexy,JDR, Metode Penelitian Kualitatif, Bandung, PT Remaja Rosdakarya, 2005.

Rina Mariana Sulaiman, 2001. Panduan Ekowisata, Berau,

Wahyuti Pratomo, 2004. Konservasi Alam
Sulistiyani, AT, Kemitraan dan Model-model pemberdayaan Masyarakat, Yogyakarta , Gaya Media, 2004

TNC (The Nature Conservancy) dan PEMKAB (Pemerintah Kabupaten Berau), 2004, Profil Pulau Derawan, Berau, TNC dan PEMKAB. 